\title{
INTEGRASI IMTAQ DAN IPTEK DALAM PEMBELAJARAN DI LINGKUNGAN LEMBAGA PENDIDIKAN ISLAM SMP PLUS AL- KAUTSAR MALANG
}

\author{
Soelaiman \\ Mahasiswa Doktoral MPI UIN Maulana Malik Ibrahim Malang \\ e-mail: Soel_imam@yahoo.com
}

\begin{abstract}
Currently in this era of globalization, there is a negative influence of the electronic media and print media on people's lives. Islamic community life that sees religion merely as a ritual activity is not conducive to improving the IMTAQ. In addition, there are many partially learners (especially in big cities) misbehaves (perkelaian students, brawling, drug abuse, sexual perversion, and other juvenile delinquency). The problems above, has not answered what the objectives of national education in an effort to increase the faith and devotion in order to achieve the life of the nation. Thus, it is not wrong if we look at the integration of science in education IMTAQ and this is a major issue that must be executed. IMTAQ integration efforts and science and technology in learning can be done in two reviews that environment-Islamic and Islamic resources.
\end{abstract}

Keywords: Integration, IMTAQ, IPTEK

\begin{abstract}
Abstrak: Saat ini di era globalisasi ini, terdapat pengaruh negatif media elektronik dan media cetak terhadap kehidupan masyarakat. Kehidupan masyarakat Islam yang memandang agama hanya sebagai kegiatan ritual belum kondusif bagi upaya peningkatan IMTAQ. Disamping itu, masih banyak sebagian peserta didik (terutama di kota-kota besar) berperilaku menyimpang (perkelaian pelajar, tawuran, penyalahgunaan narkoba, penyimpangan seksual, dan kenakalan remaja lainnya). Permasalah di atas, belumlah menjawab apa yang menjadi tujuan pendidikan nasional dalam upaya meningkatkan keimanan dan ketaqwaan dalam rangka mencerdaskan kehidupan bangsa. Dengan demikian, maka tidak salah lagi jika kita memandang pengintegrasian IMTAQ dan sains dalam pendidikan ini menjadi persoalan penting yang harus dijalankan. Upaya pengintegrasian IMTAQ dan IPTEK di pembelajaran dapat dilakukan dalam dua tinjauan yaitu lingkungan yang islami dan sumber daya yang islami.
\end{abstract}


Kata-Kata Kunci: Integrasi, IMTAQ, IPTEK

\section{Pendahuluan}

Pendidikan merupakan salah satu sarana terpenting dari sebuah bangsa atau negara dalam meningkatkan atau memajukan sumber daya manusia yang ada. Bahkan Elfindri (2011: 1) menyebutkan bahwa pendidikan merupakan salah satu strategi pembangunan yang berupaya untuk mengatasi masalah-masalah dalam pembangunan, disamping strategi lain di bidang seperti peningkatan teknologi dan pengadaan modal. Sebagai salah satu strategi dalam pembangunan, pendidikan dimaksudkan untuk menjadikan seorang individu mandiri, mampu berdiri sendiri serta menjadikan seorang individu berkembang dalam aspek kognitif, afektif maupun psikomotornya. Sebagaimana termaktub dalam UU No. 20 Tahun 2003 Tentang SISDIKNAS, yakni:

"Pendidikan adalah usaha sadar dan terencana untuk mewujudkan suasana belajar dan proses pembelajaran agar peserta didik secara aktif mengembangkan potensi dirinya untuk memiliki kekuatan spiritual keagamaan, pengendalian diri, kepribadian, kecerdasan, akhlak mulia, serta keterampilan yang diperlukan dirinya, masyarakat, bangsa dan negara."

Dari pengertian di atas, jelas bahwa tujuan dari pendidikan selain mencerdaskan individu juga dalam upaya meningkatkan keimanan dan Ketaqwaan (Imtaq) terhadap Tuhan Yang Maha Esa. Hal ini dipertegas UUD 1945 (amandemen) Pasal 31 ayat (3) yaitu "Tujuan Pendidikan Nasional meningkatkan keimanan dan ketaqwaan dalam rangka mencerdaskan kehidupan bangsa". Untuk mewujudkan tujuan manusia yang diharapkan dari kegiatan pendidikan tesebut, proses pembelajaran merupakan kegiatan penting proses pembelajaran yang akan melibatkan metode dan sistem yang digunakan dalam pendidikan.

Di sisi lain, saat ini di era globalisasi ini, terdapat pengaruh negatif media elektronik dan media cetak terhadap kehidupan masyarakat. Kehidupan masyarakat Islam yang memandang agama hanya sebagai kegiatan ritual belum kondusif bagi upaya peningkatan 
Imtaq. Disamping itu, masih banyak sebagian peserta didik (terutama di kota-kota besar) berperilaku menyimpang (perkelaian pelajar, tawuran, penyalahgunaan narkoba, penyimpangan seksual, dan kenakalan remaja lainnya).

Permasalah di atas, belumlah menjawab apa yang menjadi tujuan pendidikan nasional dalam upaya meningkatkan keimanan dan ketaqwaan dalam rangka mencerdaskan kehidupan bangsa. Dengan demikian, maka tidak salah lagi jika kita memandang pengintegrasian imtaq dan sains dalam pendidikan ini menjadi persoalan penting yang harus dijalankan. Sukri, secara spesifik spesifik, menyebutkan integrasi pendidikan iptek dan imtaq ini diperlukan karena empat alasan. Pertama, iptek akan memberikan berkah dan manfaat yang sangat besar bagi kesejahteraan hidup umat manusia bila iptek disertai oleh asas iman dan taqwa kepada Allah SWT. Sebaliknya, tanpa asas imtaq, iptek bisa disalahgunakan pada tujuan-tujuan yang bersifat destruktif. Iptek dapat mengancam nilai-nilai kemanusiaan. Jika demikian, iptek hanya absah secara metodologis, tetapi batil dan miskin secara maknawi.

Kedua, pada kenyataannya, iptek yang menjadi dasar modernisme, telah menimbulkan pola dan gaya hidup baru yang bersifat sekularistik, materialistik, dan hedonistik, yang sangat berlawanan dengan nilai-nilai budaya dan agama yang dianut oleh bangsa kita.

Ketiga, dalam hidupnya, manusia tidak hanya memerlukan kebutuhan jasmani, tetapi juga membutuhkan imtaq dan nilai-nilai sorgawi (kebutuhan spiritual). Oleh karena itu, penekanan pada salah satunya, hanya akan menyebabkan kehidupan menjadi pincang dan berat sebelah, dan menyalahi hikmat kebijaksanaan Tuhan yang telah menciptakan manusia dalam kesatuan jiwa raga, lahir dan bathin, dunia dan akhirat.

Keempat, imtaq menjadi landasan dan dasar paling kuat yang akan mengantar manusia menggapai kebahagiaan hidup. Tanpa dasar imtaq, segala atribut duniawi, seperti harta, pangkat, iptek, dan keturunan, tidak akan mampu alias gagal mengantar manusia meraih kebahagiaan. 
Artikel ini berupaya membahas terkait integrasi imtaq dan iptek dalam pembelajaran, mengenai bagaimana konsep, dan faktor kunci sukses serta pengimplementasiannya dalam lingkungan pendidikan Islam, yaitu SMP Plus Al-Kautsar Malang.

\section{Konsep Pengintegrasian IMTAQ dan IPTEK}

1. Pengertian Imtaq dan Iptek

Istilah imtaq atau kependekan dari iman dan taqwa, terdiri dari dua kata iman dan takwa yang masing-masing memiliki makna tersendiri.. Imtaq merupakan urusan yang sarat dengan nilai, kepercayaan, pemahaman, sikap, perasaan dan perilaku yang bersumber dari al-Qur'an dan Hadist.

Iman berasa dari kata amana - yu'minu - imanan yang yang secara etimologis memiliki arti kepercayaan terhadap Tuhan (Daryanto, 2007: 278). Kepercayaan ini dapat diwujudkan dengan cara membenarkan dengan hati, mengucapkan dengan lisan, dan mengamalkan dengan perbuatannya. Kepercayaan tersebut haruslah penuh dengan keyakinan, tidak bercampur dengan adanya keraguan, serta memberi pengaruh terhadap pandangan hidup, tingkah laku dan perbuatan sehari-hari. Terdapat enam rukun iman yang harus dipegang teguh oleh setiap muslim, sebagaimana sabda Rasulullah SAW, ketika beliau ditanya oleh Jibril tentang permasalahan Iman) :

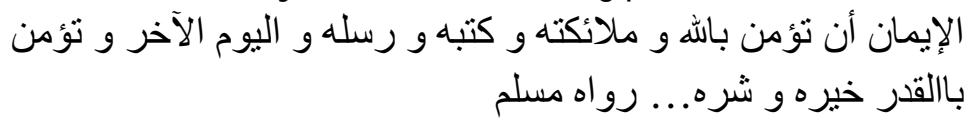

" Iman itu adalah beriman kepada Allah, malaikatmalaikatNya, kitab-kitabNya, Rasul-rasulNya, hari akhir, dan beriman kepada taqdir Allah yang baik maupun yang buruk. [HR. Muslim]

Seseorang yang beriman kepada enam rukun tersebut, harus mengikatkan hati dan perasaannya dengan kepercayaan terhadap rukun tersebut dan tidak lagi ditukarnya dengan kepercayaan lain.

Selanjutnya kata taqwa berasal dari kata waqa - yaqi - wiqayah yang artinya menjaga diri, menghindari dan menjauhi. Secara sederhana, taqwa dipahami sebagai perasaan takut kepada Allah berdasarkan kesadaran, dengan mengerjakan segala perintah-Nya dan tidak melanggar atau menjauhi segala larangan-Nya serta takut 
terjerumus dalam perbuatan dosa. Dalam kajiannya mengenai ayatayat taqwa, Irsyadunnas (2003: 506), menyimpulkan bahwa di dalam taqwa terkandung pengertian pengendalian diri oleh manusia akan dorongan emosinya dan penguasaan terhadap kecenderungan hawa nafsunya. Hal ini berarti bahwa seorang yang bertaqwa akan memenuhi dorongan-dorongan emosinya hanya sebatas yang diperkenankan oleh agama. Selain itu, dalam ungkapan taqwa juga terkandung perintah kepada manusia agar mereka senantiasa melakukan aktivitas-aktivitas yang baik yang membawa kepada kemakmuran dan kesejahteraan masyarakat, seperti: bersikap adil dalam bertindak dan berbuat, suka membantu orang-orang yang membutuhkan secara moril atau materiil, mau mengembangkan potensi diri atau intelektualitas denii mencapai kehidupan yang baik dan bermanfaat.

Berdasarkan kajian di atas, maka dapat dipahami bahwa iman dan takwa adalah merupakan dua karakteristik yang harus dimiliki setiap muslim. Kepercayaan akan membawa muslim pada keyakinan dan keteguhan akan agamanya, dan tidak akan mudah terjerumus dalam hal-hal yang mengarahkan pada kesyirikan dan kemurtadan. Sedangkan taqwa merupakan karakteristik yang akan membawa umat Islam pada kepatuhan terhadap Tuhan agar menjalankan segala perintah, menjauhi larangan serta berusaha menjadi manusia yang memiliki kepribadian dan budi pekerti yang luhur. Kedua nilai tersebut, dalam agama membutuhkan pandangan kemutlakan akan kebenaran dalam agama. Keyakinan terhadap Tuhan, Rasul, Malaikat, Kitab, Ketentuan Allah dan hari akhir membutuhkan adanya kemutlakan kepercayaan bahwa semua itu benar adanya. Disinilah kemudian terjadinya perbedaan yang mendasar antara agama dan ilmu pengetahuan

Selanjutnya, istilah 'iptek' merupakan kependekan dari 'ilmu pengetahuan dan teknologi', Istilah ini merupakan merupakan perpaduan antara ilmu pengetahuan (sains) dan teknologi, dimana keduanya merupakan dua hal yang tidak terpisahkan. Sains merupakan sumber teknologi dan teknologi merupakan aplikasi sains. Baiquni (1997: 63) mendefinisikan sains atau ilmu pengetahuan sebagai himpunan rasional kolektif insan, tentang alam yang diperoleh 
melalui konsensus para pakar. Sedangkan teknologi adalah sebagai himpunan pengetahuan terapan manusia tentang proses-proses pemanfaatan alam yang diperoleh dari penerapan sains, dalam kegiatan yang produktif ekonomis.

Teknologi yang merupakan penerapan konsep ilmiah, yang tidak hanya bertujuan menjelaskan gejala-gejala alam untuk tujuan pengertian dan pemahaman, namun lebih jauh lagi bertujuan memanipulasi faktor- faktor yang terkait dengan gejala-gejala tersebut, untuk mengontrol dan mengarahkan proses yang terjadi, sehingga teknologi bisa berfungsi sebagai sarana memberikan kemudahan bagi kehidupan manusia. Dengan kata lain, teknologi adalah penerapan sains secara sistematis untuk mempengaruhi dan mengendalikan alam di sekeliling kita, dalam suatu proses produktif ekonomis untuk menghasilkan sesuatu yang bermanfaat bagi umat manusia (Ali Anwar Yusuf, 2000: 279 - 280).

Dari paparan diatas, dapat dipahami bahwa ilmu pengetahuan memiliki cara yang berbeda dalam mendapatkan kebenaran. Kebenaran dalam ilmu pengetahuan mensyaratkan adanya bukti empiris. Dalam kasus kepercayaan terhadap Tuhan, tentu akan sulit untuk membuktikan keberadaan Tuhan secara empiris. Itulah sebabnya keduanya sering dipandang sebagai konsep dikotomis, yang memiliki perbedaan sudut pandang yang cukup tajam.

\section{Hubungan Antara Imtaq Dan Iptek}

Secara bahasa integrasi memiliki arti pembauran hingga menjadi kesatuan yg utuh atau bulat. Dengan demikian, Integrasi dapat dimaknai sebagai proses memadukan satu konsep tertentu dengan sebuah konsep lain, sehingga menjadi suatu kesatuan yang koheren dan tidak bisa dipisahkan atau proses pembauran hingga menjadi satu kesatuan yang utuh dan bulat.

Imtaq atau iman dan taqwa, pada dasarnya keduanya merupakan gambaran karakteristik nilai-nilai keagamaan (ke-Islaman) yang harus dimiliki oleh setiap muslim sebagai penganut agama Islam. Dengan demikian, konsep pengintegrasian imtaq dan iptek ini dapat dipandang dari sisi perpaduan antara dimensi agama dan ilmu pengetahuan menjadi satu kesatuan yang utuh. 
Dalam sejarahnya, telah terjadi pendikotomian keilmuwan terhadap agama dan ilmu pengetahuan. Keduanya dipandang memiliki kutub masing-masing yang terpisah secara ekstrim. Keduanya telah terjebak dalam subyektivitasnya masing-masing, terutama dalam hal klaim kebenaran. Ilmuwan menganggap bahwa kebenaran versi agama adalah kebenaran imajiner dan itu tidak lebih dari sekedar mimpi, Sebaliknya, kaum agamawan menyebut kebenaran sains adalah kebenaran emosional, tidak konprehensif karena hanya bersifat materi dan tidak dapat mengantarkan pada kebahagiaan hakiki. Barbour menyebut hubungan sains dan agama ini sebagai sebuah konflik (Ian G. Barbour, 2002: 54).

Pendikotomian ini pada akhirnya merambah ke wilayah pendidikan. tujuan pendidikan Islam yang hanya diorientasikan kepada kehidupan akhirat semata dan cenderung bersifat defensive, telah diidentikkan dengan Barat, dan dianggap sebagai ancaman serius yang dapat mencermarkan agama Islam. Hal ini pula yang menjadi salah satu sebab munculnya dikhotomi ilmu dalam pendidikan Islam: ilmu dunia/ sekuler (Barat) dan ilmu akhirat/ agama (Islam) (Haidar Bagir, 1999: 123). Faruqi sebagaimana dikutip oleh Abuddin (2002: 151 - 152) mengungkapkan bahwa pendikotomian ini merupakan simbol kejatuhan umat Islam. Dikotomi keilmuan dianggap sebagai penyebab kemunduran berkepanjangan umat Islam yang sudah berlangsung sejak abad ke-16 hingga abad ke-17 yang dikenal sebagai abad stagnasi pemikiran Islam. Dikotomi ini pada kelanjutannya berdampak negatif terhadap kemajuan umat.

Islam pada dasarnya tidak memandang ilmu agama (imtaq) dan ilmu umum (iptek) terpisah, karena keduanya berasal dari sumber yang satu, yaitu Allah swt. Pengetahuan dalam agama adalah pengetahuan yang bersumber langsung dari Allah swt, dalam bentuk wahyu yang diturunkan melalui Nabi Muhammad saw sebagai rasulnya. agama merupakan ajaran (dokrin) yang sumbernya dari Tuhan, sehingga kebenaran timbul mengikuti proses wahyu yang datang dari Tuhan melalui suatu perantara, adapun ketika wahyu itu sudah turun, maka manusia dapat mencari kebenaran agama dengan mempelajari sumber utama dari agama yang dimaksud, dalam hal ini Kitab Suci, ( Al Qur'an, Sunnah dan Ijtihad). 
Sedangkan pengetahuan dalam bentuk iptek, pada dasarnya juga berasal dari Allah, yang didapat oleh manusia melalui alam, akal/nalar manusia yang diciptakan oleh Allah swt. Agama Islam menghendaki umatnya selalu belajar, termasuk mempelajari alam. Seperdelapan ayat-ayat al Qur'an atau \pm 750 ayat adalah ayat-ayat kauniyah yaitu ayat-ayat yang berhubungan dengan gejala-gejala alam yang semuanya merangsang, menegur dan mendorong umat Islam untuk melakukan kegiatan yang menuju pada pengembangan sains (Milya Sari, 2002: 72).

Hubungan antara agama dan sains sendiri pada dasarnya memiliki hubungan yang saling mendukung satu sama lain. Sebagaimana yang dihelaskan Bagir dkk (2005: 45 - 46) mengemukakan bahwa ilmu mampu membantu agama merevitalisasi diri dengan beberapa cara.

a) Kesadaran kritis dan sikap realistis yang dibentuk oleh ilmu sangat berguna untuk mengelupaskan sisi sisi ilusoris agama, bukan untuk menghancurkan agama, melainkan untuk menemukan hal-hal yang lebih esensial dari agama. Dalam praksisnya, banyak hal dalam kehidupan beragama yang mungkin saja bersifat ilusoris, yang membuat agama-agama bersifat oversensitive sehingga mudah menimbulkan konflik yang akhirnya justru menggerogoti martabat agama sendiri tanpa disadari.

b) Kemampuan logis dan kehati-hatian mengambil kesimpulan yang dipupuk dalam dunia ilmiah menjadikan kita mampu menilai secara kritis segala bentuk tafsir baru yang kini makin hiruk pikuk dan membingungkan.

c) Lewat temuan-temuan barunya, ilmu dapat merangsang agama untuk senantiasa tanggap memikirkan ulang keyakinankeyakinannya secara baru dengan begitu menghindarkan agama itu sendiri dari bahaya stagnasi dan pengaratan.

d) Temuan-temuan ilmu pengetahuan dan teknologi pun dapat memberi peluang-peluang baru bagi agama untuk makin mewujudkan idealism-idealismenya secara konkret, terutama yang menyangkut kemanusiaan umum. 
Sebaliknya, Agama pun sebetulnya dapat membantu ilmu agar tetap manusiawi dan selalu menyadari persoalan-persoalan konkret yang harus dihadapinya. Manfaat agama dalam membantu ilmu antara lain:

a) Agama dapat selalu mengingatkan bahwa ilmu bukanlah satusatunya jalan menuju kebenaran dan makna terdalam kehidupan manusia. Dalam dunia manusia, terdapat relitas pengalaman batin yang membentuk makna dan nilai. Hal itu merupakan wilayah yang tidak banyak disentuh oleh ilmu, wilayah yang ambigu tetap riil.

b) agama dapat juga selalu mengingatkan ilmu dan teknologi untuk senantiasa membela nilai kehidupan dan kemanusiaan bahkan di atas kemajuan pengetahuan itu sendiri.

c) Ketiga, agama dapat membantu ilmu memperdalam penjelajahan di wilayah kemungkinankemungkinan adikodrati atau supranatural. Apalagi jika wilayah-wilayah itu memang merupakan ujung tak terelakkan dari aneka pencarian ilmiah yang serius saat ini. Keempat, agama pun dapat selalu menjaga sikap mental manusia gar tidak mudah terjerumus kedalam mentalitas pragmatis instrumental, yang menganggap bahwa sesuatu dianggap bernilai sejauh jelas manfaatnya dan dapat diperalat untuk kepentingan manusia.

Dari berbagai paparan diatas, dapat dipahami bahwa hubungan antara imtaq dan iptek harusnya tidak dipandang sebagai sesuatu yang dikotomis, justru sebaliknya keduanya saling memberikan manfaat yang sama pentingnya. Pada kenyataannya konsep pendikotomian telah gagal dalam upaya membangun umat. Agama yang terejawantah dalam nilai keimanan dan ketaqwaan dalam diri seseorang akan mengelola bumi dengan bijak. Sedangkan sains akan menuntut manusia untuk meningkatkan kehidupan ke arah yang lebih baik.

\section{Pengintegrasian IMTAK Dan IPTEK dalam Pembelajaran}

Pembelajaran merupakan bagian penting dari sebuah kegiatan pendidikan. Dick dan Carey (2006: 205) mendefinisikan pembelajaran sebagai rangkaian peristiwa atau kegiatan yang disampaikan secara terstruktur dan terencana dengan menggunakan sebuah atau beberapa 
jenis media. Hal senada juga disampaikan Gagne sebagaimana dikutip oleh Pribadi (2011: 9), bahwa pembelajaran merupakan serangkaian aktivitas yang sengaja diciptakan dengan maksud untuk memudahkan terjadinya proses belajar.

Dari kedua definisi tersebut dapat dipahami bahwa pembelajaran menitikberatkan pada kegiatan atau aktivitas, yang dilakukan, yaitu membuat pembelajar mengalami proses belajar. Dalam hal ini lebih detail Yamin (2011: 69) mengemukakan bahwa pembelajaran adalah kemampuan dalam mengelola secara operasional dan efisien terhadap komponen-komponen yang berkaitan dengan pembelajaran, sehingga menghasilkan nilai tambah terhadap komponen tersebut menurut norma atau standar yang berlaku. Dengan demikian, kegiatan pembelajaran akan meliputi kegiatan mengelola komponen komponen yang dibutuhkan dalam kegiatan belajar mengajar. Dalam hal ini kegiatan pembelajaran tidak akan menitikberatkan pada apa yang dipelajari, tetapi menitikberatkan pada aktivitas atau kegiatan yan harus dilakukan, untuk mencapai tujuan yang berkaitan dengan cara pengorganisasian materi, cara penyampaian pelajaran dan cara mengelola pembelajaran.

Dalam kaitan dengan kurikulum, maka pembelajaran berfungsi sebagai implementasi yang telah dituangkan dan ditafsirkan secara bersama-sama serta dilaksanakan. Proses pembelajaran mempunyai tujuan agar siswa dapat mencapai kompetensi seperti yang diharapkan. Untuk mencapai tujuan tersebut proses pembelajaran perlu dirancang secara sistematik dan terstruktu baik. Dalam hal ini, seorang pengajar harus membuat perencanaan yang baik terhadap pembelajarannya, agar peserta didik dapat menguasai atau mencapai target yang telah ditetapkan dengan melibatkan strategi ikut mengiringi dalam setiap prosesnya.

Konsep pengintegrasian iptek dan imtaq dalam pembelajaran pada dasarnya merupakan konsep turunan dari keinginan untuk mengintegrasikan pendidikan Islam secara keseluruhan. Allah menciptakan manusia untuk menjadi kholifah dimuka bumi, yang akan membentuk peradaban yang baik dan tinggi. Alqur'an telah memberikan referensi tentang pentingnya ilmu, untuk dapat 
dikembangkan manusia menuju peradapan yang lebih baik. Sebagaimana tercantum dalam Qs. Al Mujadalah ayat 11

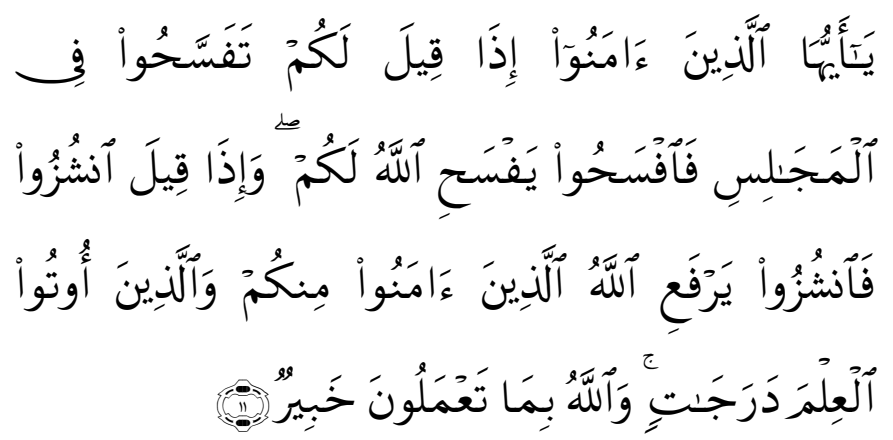

Hai orang-orang beriman apabila kamu dikatakan kepadamu: "Berlapang-lapanglah dalam majlis", Maka lapangkanlah niscaya Allah akan memberi kelapangan untukmu. dan apabila dikatakan: "Berdirilah kamu", Maka berdirilah, niscaya Allah akan meninggikan orang-orang yang beriman di antaramu dan orang-orang yang diberi ilmu pengetahuan beberapa derajat. dan Allah Maha mengetahui apa yang kamu kerjakan.

Dari ayat di atas dapat dipahami bahwa pendidikan harusnya menjadi bagian dari seseorang dalam memperkuat keimanan dan ketaqwaanya, karena Allah telah menjanjikan derajat yang lebih tinggi bagi orang yang berilmu pengetahuan. Islam tidak membedakan antara antara agama dan ilmu pengetahuan lainnya. Keduanya saling melengkapi dan harus dipelajari secara langsung sebagai sebuah sistem pendidikan yang terintegrasi, yang tujuan akhirnya adalah kebaikan di dunia dan akhirat kelak.

Dalam pengintegrasian ini, mungkin kita harus sependapat dengan Soewardi (2001: 1 - 24) yang berpandangan bahwa abad 20 merupakan akhir dari Sains Barat Sekuler (SBS) yang telah melahirkan krisis global dan menghasilkan 3R (Renggut, Resah, Rusak). Abad ini adalah momentum menuju lahirnya Sains Tauhidullah atau sains Islami. Sains tauhidullah tiada lain adalah alternatif terhadap SBS yang kini sudah hampir kandas. Islamisasi sains bukanlah mengislamkan sains, akan tetapi mencari kelanjutan SBS yang pada penghujung abad 20 sampai pada 3 R. Karakteristik utama sains tauhidullah adalah 
naqliyah memandu aqliyah atau wahyu yang memandu fitrah atau akal manusia. Kecenderungan akan lahir dan berkembangnya sains tauhidullah tersebut tentunnya harus berimplikasi pada proses transfer of knowledge semua disiplin ilmu yang menjadi muatan kurikulum pada satuan pendidikan, terlebih bagi madrasah yang menjadikan agama Islam sebagai identitas kelembagaan.

Dengan demikian, pengimplementasian pengintegrasian imtaq dan iptek dalam pembelajaran membutuhkan adanya seperangkat kurikulum yang mendukung baik dalam proses pelaksanaan pembelajaran itu sendiri maupun kegiatan diluar proses pembelajaran. Pengintegrasian imtaq dan iptek, sebagai satu kesatuan ini dicontohkan sauri, sebagaiman kegiatan-kegiatan berikut ini.

1. Penataan sarana fisik sekolah yang mendukung proses internalisasi nilai IMTAK dalam pembelajaran.

2. Pendirian sarana Ibadah yang memadai

3. Membiasakan membaca al quran/tadarus setiap mengawali PBM

4. Membiasakan memperdengarkan lantunan-lantunan Al qur'an setiap ketika akan masuk kelas, jam istirahat dan jam pulang melalui radio kelas.

5. Pembinaan $\mathrm{Al}$ quran dan $\mathrm{Al}$ Hadist secara rutin

6. Adanya pola pembinaan keagamaan guru secara terprogram dan terpola serta adanya Wakil Kepala yang secara khusus membidangi program pembinaan Iman dan Taqwa Guru dan Siswa.

7. Membiasakan menghubungkan setiap pembahasan disiplin ilmu tertentu dengan perspektif ilmu agama (AL qur'an dan Hadist)

8. Membiasakan shalat berjamaah.

9. Mengupayakan adanya kuliah dhuha dan kuliah tujuh menit setiap ba'da shalat dzuhur.

10. Dibiasakanya shalat jumat berjamaah di sekolah (Imam dan Khotib oleh Guru secara bergiliran) dan dibuatnya buletin jumatan serta adanya kajian keislaman setiap ba'da jumatan

11. Program keputrian bagi Guru perempuan

12. Membudayakan ucapan salam di lingkungan sekolah 
13. Memberikan hukuman bagi siswa yang berbuat pelanggaran seperti kesiangan dengan hukuman hapalan Al qur'an.

14. Adanya program BP yang berbasis nilai-nilai Iman dan Taqwa

15. Membiasakan menghentikan semua aktifitas setiap tiba waktu shalat dan adanya petugas keamanan sekolah bagi siapapaun yang tidak mengerjakan shalat berjamaah.

16. Adanya ketauladanan (Personal Image) dan kontrol sosial dari kepala sekolah terhadap prilaku guru.

17. Adanya penataan yang tertib tentang tempat guru akhwat dan ikhwan

18. Dibuatkanya tata tertib kerja secara bersama (sebagai acuan dan alat kotrol) yang memperhatikan nilai-nilai IMTAQ.

19. Kajian rutin tentang dunia profesi keguruan dalam perspektif agama Tablig akbar secara rutin

20. Pembinaan Tulis dan Baca Qur'an (TBQ) bagi Guru

21. Slogan-slogan motivasi di lingkungan sekolah

22. dan lain-lain

Pengimplementasian diatas, membutuhkan komitmen yang kuat dari stakeholder internal sekolah dan juga membutuhkan dukungan dari stakeholder eksternal sekolah.

\section{Faktor Kunci Sukses Pengintegrasian IMTAQ dan IPTEK Dalam Pembelajaran}

Dalam konteks pendidikan formal, pendidikan budi pekerti selama ini dibebankan pada mata pelajaran PAI dan PKn. Kedua mata pelajaran tersebut tak jarang menjadi "kambing hitam" ketika terjadi perilaku menyimpang di kalangan siswa. PAI dan PKn dianggap telah gagal membentuk siswa menjadi manusia yang berbudi pekerti luhur. Padahal, jika kita mau objektif dan merenung, pembinaan budi pekerti bukan hanya tugas guru PAI dan PKn, tetapi tugas semua guru di sekolah dan dapat diintegrasikan dalam berbagai kegiatan di sekolah serta bekerjasama dengan orang tua siswa/masyarakat.

Mempercayakan pendidikan pembinaan Imtaq peserta didik hanya kepada satu mata pelajaran mengandung kelemahan. Baik dari segi hakikat pendidikan nasional sebagai suatu sistem maupun hakekat proses pendidikan yang ideal, yaitu yang mampu mengembangkan 
semua dimensi kepribadian peserta didik secara utuh seperti yang dinyatakan dalam GBHN dan UU Sisdiknas (Dedi Supriadi, 2004: 121).

Misalnya, seorang guru olah raga, selain mengajarkan teknikteknik olah raga juga menyelipkan nilai-nilai sportivitas sebagai ruh dari olah raga. Seorang guru fisika, biologi, atau geografi ketika menjelaskan tentang tata surya, makhluk hidup, atau bumi, disertai atau diperkuat dengan ayat-ayat dalam Al-Qur'an yang menjelaskan hal tersebut. Seorang guru ekonomi, ketika menjelaskan tentang perdagangan dan distribusi barang dapat menyelipkan nilai imtaq berupa dilarang mengurangi timbangan, menjunjung tinggi kejujuran dalam berdagang, dilarang memonopoli, dan dilarang melakukan penimbunan barang yang berakibat menyengsarakan banyak orang. Seorang guru Teknologi Informasi dan Komunikasi (TIK) bukan hanya mengajarkan bagaimana menguasai perangkat TIK, tetapi perlu ditekankan bahwa teknologi perlu digunakan untuk kebaikan umat manusia, bukan sebaliknya, merusak umat manusia dan lingkungan.

Disisi lain, Pendidikan kita saat ini lebih berorientasi hasil pada ranah kognitif berupa hafalan-hafalan, sementara ranah afektif belum diperhatikan secara serius sehingga para siswa mengalami degradasi moral dan kemunduran dalam budi pekerti. Tidak jarang ada siswa yang mendapat nilai tinggi tetapi dicapai dengan cara nyontek, sikap dan perilakunya pun kurang terpuji. Tidak heran jika hasil pendidikan yang hanya mengejar nilai menghasilkan generasi yang kurang peka terhadap lingkungan. Akibatnya banyak lembaga pendidikan menghasilkan kekerasan alias premanisme di lingkungan sekolah.

Keimanan dan ketaqwaan siswa merupakan core tujuan pendidikan nasional. Untuk mencapai tujuan tersebut, lembaga pendidikan sekolah yang efektif dinilai merupakan salah satu wahana yang sangat efektif untuk mencapai tujuan pendidikan, dengan alasan karena melalui proses pendidikan di sekolah peserta didik akan memperoleh bukan saja aspek pengetahuan dan keterampilan, tetapi juga sikap. Dalam rangka peningkatan keimanan dan ketakwaan siswa melalui lembaga pendidikan sekolah, Direktorat Jenderal Manajemen Pendidikan Dasar dan Menengah telah mengembangkan lima strategi, yakni (1) optimalisasi pelaksanaan Pendidikan Agama Islam, (2) integrasi Iptek dan Imtaq dalam proses pembelajaran, (3) pelaksanaan 
kegiatan ekstra kurikuler berwawasan Imtaq, (4) penciptaan situasi yang kondusif dalam kehidupan sosial di sekolah, dan (5) melaksanakan kerjasama antara sekolah dengan orangtua dan masyarakat.

Sesuai dengan perubahan struktur organisasi Direktorat Jenderal Pendidikan Dasar dan Menengah menjadi Direktorat Jenderal Manajemen Pendidikan Dasar dan Menengah, dipandang perlu dibangun paradigma baru yang relevan dengan program peningkatan Imtaq dengan melibatkan seluruh komponen sekolah, termasuk pemangku kepentingan sekolah atau stakeholders pendidikan. Paradigma baru ini kemudian dikenal dengan Pemberdayaan Sekolah Berwawasan Imtaq, yang kegiatannya meliputi (1) semiloka peningkatan Imtaq Siswa, (2) Integrasi Imtaq-Iptek dalam proses pembelajaran di sekolah, (3) Bulletin/ Poster Religiusitas, (4) Lomba Karya Tulis Peningkatan Imtaq, dan (5) Pemberian Subsidi Pemberdayaan Sekolah Berwawasan Imtaq.

Dalam pengintegrasian imtaq dan iptek tersebut memang menjadi peran seluruh stakeholder untuk bisa mensukseskannya. Berikut merupakan faktor pendorong kesuksesan yang harus diperhatikan dalam upaya mengintegrasikan imtaq dan iptek dalam pembelajaran (Lubis, 2009: 51 - 60):

\section{Tenaga Pendidik Dan Kependidikan}

Guru dan para pegawai administratif yang berada dilingkungan pendidikan, harusnya telah siap untuk mengubah pemikiran dan sikap mereka untuk menerima dan memahami pengintegrasian iptek dan imtaq sebagai satu kesatuan yang holistik. Integrasi ini bukan hanya untuk murid (student-oriented), tetapi juga untuk guru (teacher oriented). Guru harusnya juga dilatih untuk mengubah paradigma berpikir dan sikap mereka agar menunjukkan perilaku yang baik sesuai dengan nilai-nilai Islam yang nantinya akan menjadi contoh atau teladan bagi murid-muridnya. Dengan demikian, kriteria dalam pengambilan guru kedepannya, harus seimbang tidak hanya melihat pencapaian akademiknya, tetapi juga melihat harus memiliki good personality.

Untuk mendukung hal ini, guru-guru yang dihasilkan oleh kampus-kampus, harusnya telah mengenal dan memahami paradigma 
pengintegrasian iptek dan imtaq ini, sehingga nantinya mereka dapat mendorong peningkatan dan perkembangan mental yang baik pada anak didik mereka. Selain itu, kurikulum juga harus dianalisis agar mengarah pada filsafat pengintegrasian imtaq dan iptek tersebut, sehingga guru-guru memiliki kesempatan untuk berinovasi, mencurahkan aspirasi, dan memiliki role-model yang baik dalam kegiatan mengajar mereka.

Pengintegrasian iptek dan imtaq tidak akan efektf jika guru tidak diberikan latihan yang cukup mengenai cara-cara mengajar materi yang terintegrasi. oleh karena guru merupakan katalisator dalam sebuah sistem pendidikan, maka merekalah yang harusnya pertama kali memahami konsep, filosofi dan tujuan dari pengintegrasian iptek dan imtaq ini dalam kegiatan pembelajaran yang mereka lakukan. Guru harus benar-benar terlatih dengan baik bagaimana menjadi lebih inovatif dalam mempersiapkan materi belajar mereka. Ini harusnya tidak hanya sekedar menjadi teori tetapi benar-benar ide yang dapat terimplementasi dengan baik.

Berdasarkan Undang-undang Sistem Pendidikan Nasional (UUSPN) tahun 2003 pasal 1 disebutkan bahwa tenaga kependidikan adalah anggota masyarakat yang mengabdikan diri dan diangkat untuk menunjang penyelenggaraan pendidikan. Sedangkan, pendidik adalah tenaga kependidikan yang berkualifikasi sebagai guru, dosen, konselor, pamong belajar, widyaiswara, tutor, instruktur, fasilitator, dan sebutan lain yang sesuai dengan kekhususannya, serta berpartisipasi dalam menyelenggarakan pendidikan.

Tugas tenaga kependidikan sebagaimana disebutkan pada pasal 39 ayat 1 adalah melaksanakan administrasi, pengelolaan, pengawasan dan pelayanan teknis untuk menunjang proses pendidikan pada satuan pendidikan. Sedangkan pada ayat 2 disebutkan bahwa pendidik merupakan tenaga profesional yang bertugas merencanakan dan melaksanakan proses pembelajaran, melakukan pembimbingan dan pelatihan, serta melakukan penelitian dan pengabdian kepada masyarakat, terutama bagi pendidik pada perguruan tinggi.

Berdasarkan Peraturan Pemerintah Republik Indonesia No. 38 tahun 1992 Bab II pasal 3 ayat 1, tenaga kependidikan terdiri atas 
tenaga pendidik, pengelola satuan pendidikan, penilik, pengawas, peneliti dan pengembangan di bidang pendidikan, pustakawan, laboran, teknisi sumber belajar dan penguji. Pada ayat 2 dipertegas bahwa tenaga pendidik terdiri atas pembimbing, pengajar, dan pelatih. Selanjutnya, ayat 3 mengemukakan bahwa pengelola satuan pendidikan terdiri dari kepala sekolah, direktur, ketua, rektor, dan pimpinan satuan pendidikan di luar sekolah.

Sebagai bagian dari SDM yang ada di lembaga pendidikan, pendidik merupakan ujung tombak dalam proses pendidikan Islam. Proses pendidikan Islam tidak akan berhasil dengan baik tanpa adanya peran guru atau pendidik. Secara institusional, kemajuan suatu lembaga pendidikan lebih ditentukan oleh pimpinan lembaga tersebut daripada oleh pihak lain. Tetapi, dalam proses pembelajaran, guru memiliki peran yang lebih daripada metode atau materi. Sebagaimana ungkapan A. Malik Fadjar, "Al-thariqah ahammu min al-maddah walakinna al-mudarris ahammu min al-thariqah". Yang artinya, metode lebih penting daripada materi, tetapi guru lebih penting daripada metode (Qomar, 2007: 129).

Peran penting guru dalam pendidikan merupakan potensi besar dalam memajukan atau meningkatkan mutu pendidikan Islam, atau dapat menghancurkannya. Ketika guru benar-benar berlaku profesional dan dapat mengelola pendidikan dengan baik, maka mereka akan bersemangat dalam menjalankan tugasnya bahkan rela melakukan inovasi-inovasi pembelajaran untuk mewujudkan kesuksesan pembelajaran peserta didik. Tetapi, jika para guru terlantar akibat tindakan pimpinan, maka mereka justru akan menjadi penghambat paling serius terhadap proses pendidikan Islam (Qomar, 2007: 129). Maka, dalam hal ini, peran pemimpin sangat penting dalam mengelola guru-guru yang ada di sekolah bersangkutan. Sebagai puncak pimpinan tertinggi dan penanggung jawab pelaksanaan otonomi pendidikan di tingkat sekolah/madrasah, kepala sekolah memiliki peran sentral dalam pengelolaan pendidik dan tenaga kependidikan (Baharuddin, 2010: 63).

Selain itu pegawai administratif juga memiliki peran yang tidak kalah pentingnya, utamanya dalam membangun budaya berlandaskan keimanan dan ketaqwaan. Para pegawai dapat menanamkan nilai-nilai 
keIslaman seperti kedisiplinan, menjaga kebersihan, bertutur kata yang sopan dan sebagainya. dari uraian ini dapat disimpulkan bahwa mengintegrasikan imtaq dan iptek dalam pembelajaran menjadi tidak hanya menjadi tanggung jawab guru, tetapi seluruh stakeholder sekolah.

2. Textbook (buku)

Buku memiliki peranan penting dalam kegiatan pembelajaran. Selama ini, buku-buku yang ada memang masih belum mengintegrasikan Imtaq dalam materinya. Pengintegrasian ini bisa melalui penambahan materi penanaman nilai-nilai kemanusiaan, atau bahkan bisa mengarah pada penyertaan ayat-ayat al-Qur'an yang sesuai dengan tema ilmu pengetahuan yang diajarkan. Dalam hal ini menteri pendidikan memiliki peranan yang penting dalam membuat dan mendistribusikan buku-buku yang telah teritegrasi.

3. Peran Penting Guru

Tugas seorang guru adalah mendidik dan mengajar siswa. Dalam Islam, tugas guru sangatlah mulia, bahkan dapat disebut sebagai penerus misi nabi Muhammad SAW. Dalam mengintegrasikan iptek dan imtaq, tugas guru memberikan tambahan nilai-nilai dalam setiap mata pelajaran yang diajarkan. Guru harus melengkapi pribadi mereka dengan pengetahuan, ketrampilan, personality, sikap dan perilaku yang baik untuk menjadikan dirinya contoh (role model) bagi siswasiswanya.

Selain empat kompetensi tersebut, ada kompetensi lain yang harus dimiliki oleh para pendidik, yaitu kompetensi moral dan spiritual (Mulyasa, 2010: 35). Secara konseptual, unjuk kerja guru menurut Depdikbud (Yamin, 2011:4 - 5) mencakup tiga aspek, yaitu:

a. Kemampuan profesional mencakup: (1) Penguasaan materi pelajaran yang terdiri atas penguasaan bahan yang harus diajarkan, dan konsep-konsep dasar keilmuan dari bahan yang diajarkannya itu. (2) Penguasaan dan penghayatan atas landasan dan wawasan kependidikan dan keguruan. (3) Penguasaan proses-proses kependidikan, keguruan dan pembelajaran siswa.

b. Kemampuan sosial mencakup kemampuan untuk menyesuaikan diri kepada tuntutan kerja dan lingkungan sekitar pada waktu membawa tugasnya sebagai guru. 
c. Kemampuan personal (pribadi) mencakup: (1) Penampilan sikap yang positif terhadap keseluruhan tugasnya sebagai guru, dan terhadap keseluruhan situasi pendidikan beserta unsur-unsurnya. (2) Pemahaman, penghayatan dan penampilan nilai-nilai yang seyogyanya dianut oleh seorang guru. (3) Penampilan yang merupakan upaya untuk menjadikan dirinya sebagai panutan dan teladan bagi para siswanya.

Syarat menjadi guru harus sehat jasmani dan rohani, menunjukkan bahwa tugas guru adalah tugas yang berat lahir dan batin. Guru tidak mungkin dapat melakukan pembelajaran kalau selalu dalam keadaan sakit jasmani, atau guru memiliki penyakit yang menular yang akan menjangkiti siswa-siswanya, kesehatan jasmani akan menopang keberhasilan guru mengajar di kelas. Jadi, guru dituntut prima, cekatan dan berwibawa dalam memberi pembelajaran. Disamping itu, tidak dibenarkan menjadi guru bagi orang yang tidak sehat secara rohani (Yamin, 2011: 80 - 81).

4. Kegiatan Ekstrakurikuler Yang Mendukung

Berdasarkan Pasal 3 Undang-Undang Nomor 20 Tahun 2003 tentang Sistem Pendidikan Nasional menyebutkan bahwa pendidikan nasional bertujuan untuk berkembangnya potensi peserta didik agar menjadi manusia yang beriman dan bertakwa kepada Tuhan Yang Maha Esa, berakhlak mulia, sehat, berilmu, cakap, kreatif, mandiri, dan menjadi warga negara yang demokratis serta bertanggung jawab.

Pengembangan potensi peserta didik sebagaimana dimaksud dalam tujuan pendidikan nasional tersebut dapat diwujudkan melalui kegiatan ekstrakurikuler yang merupakan salah satu kegiatan dalam program kurikuler. Kegiatan ekstrakurikuler adalah program kurikuler yang alokasi waktunya tidak ditetapkan dalam kurikulum. Jelasnya bahwa kegiatan ekstrakurikuler merupakan perangkat operasional (supplement dan complements) kurikulum, yang perlu disusun dan dituangkan dalam rencana kerja tahunan/ kalender pendidikan satuan pendidikan.

Kegiatan ekstrakurikuler menjembatani kebutuhan perkembangan peserta didik yang berbeda; seperti perbedaan sense akan nilai moral dan sikap, kemampuan, dan kreativitas. Melalui partisipasinya dalam kegiatan ekstrakurikuler peserta didik dapat 
belajar dan mengembangkan kemampuan berkomunikasi, bekerja sama dengan orang lain, serta menemukan dan mengembangkan potensinya. Kegiatan ekstrakurikuler juga memberikan manfaat sosial yang besar.

Kegiatan ekstrakurikuler merupakan salah satu perangkat operasional (supplement dan complements) kurikulum, yang perlu disusun dan dituangkan dalam rencana kerja tahunan/kalender pendidikan satuan pendidikan (seperti disebutkan pada Pasal 53 ayat (2) butir a Peraturan Pemerintah Nomor 19 Tahun 2005 tentang Standar Nasional Pendidikan sebagaimana telah diubah dengan Peraturan Pemerintah Nomor 32 Tahun 2013 tentang Perubahan Atas Peraturan Pemerintah Nomor 19 Tahun 2005 tentang Standar Nasional Pendidikan) serta dievaluasi pelaksanaannya setiap semester oleh satuan pendidikan (seperti disebutkan pada Pasal 79 ayat (2) butir b Peraturan Pemerintah Nomor 19 Tahun 2005 tentang Standar Nasional Pendidikan sebagaimana telah diubah dengan Peraturan Pemerintah Nomor 32 Tahun 2013 tentang Perubahan Atas Peraturan Pemerintah Nomor 19 Tahun 2005 tentang Standar Nasional Pendidikan).

Ekstrakurikuler adalah kegiatan pendidikan yang dilakukan oleh peserta didik di luar jam belajar kurikulum standar sebagai perluasan dari kegiatan kurikulum dan dilakukan di bawah bimbingan sekolah dengan tujuan untuk mengembangkan kepribadian, bakat, minat, dan kemampuan peserta didik yang lebih luas atau di luar minat yang dikembangkan oleh kurikulum. Berdasarkan definisi tersebut, maka kegiatan di sekolah atau pun di luar sekolah yang terkait dengan tugas belajar suatu mata pelajaran bukanlah kegiatan ekstrakurikuler.

Kegiatan ekstrakurikuler pada satuan pendidikan memiliki fungsi pengembangan, sosial, rekreatif, dan persiapan karir, yang dapat dijelaskan sebagaiman berikut:

a. Fungsi pengembangan, yakni bahwa kegiatan ekstrakurikuler berfungsi untuk mendukung perkembangan personal peserta didik melalui perluasan minat, pengembangan potensi, dan pemberian kesempatan untuk pembentukan karakter dan pelatihan kepemimpinan. 
b. Fungsi sosial, yakni bahwa kegiatan ekstrakurikuler berfungsi untuk mengembangkan kemampuan dan rasa tanggung jawab sosial peserta didik. Kompetensi sosial dikembangkan dengan memberikan kesempatan kepada peserta didik untuk memperluas pengalaman sosial, praktek keterampilan sosial, dan internalisasi nilai moral dan nilai sosial.

c. Fungsi rekreatif, yakni bahwa kegiatan ekstrakurikuler dilakukan dalam suasana rileks, menggembirakan, dan menyenangkan sehingga menunjang proses perkembangan peserta didik. Kegiatan ekstrakurikuler harus dapat menjadikan kehidupan atau atmosfer sekolah lebih menantang dan lebih menarik bagi peserta didik.

d. Fungsi persiapan karir, yakni bahwa kegiatan ekstrakurikuler berfungsi untuk mengembangkan kesiapan karir peserta didik melalui pengembangan kapasitas.

Dengan dilaksanakannnya kegiatan ekstrakurikuler, maka diharapkan dapat meningkatkan kemampuan kognitif, afektif, dan psikomotor peserta didik. Serta dapat mengembangkan bakat dan minat peserta didik dalam upaya pembinaan pribadi menuju pembinaan manusia seutuhnya.

\section{Implementasi Integrasi IMTAQ dan IPTEK di Lingkungan Lembaga Pendidikan Islam SMP Plus Al-Kaustar Malang}

1. Sekilas mengenai SMP Plus Al-Kautsar Malang

SMP Plus Al-Kautsar Malang merupakan salah satu bagian bagian dari yayasan Pelita Hidayah yang bergerak dalam bidang pendidikan selain TK Plus Al Kautsar Malang (1999) yang berlokasi di Jl. LA. Sucipto 99 Malang dan SD Plus Al Kautsar (2004) yang berlokasi di Jl. Simpang LA. Sucipto 22/ 338 Malang. SMP Plus Al Kautsar berdiri pada tahun pelajaran: 2010/ 2011 dengan surat keputusan (SK) Kepala Dinas Pendidikan Kota Malang Nomor: 421.8/4394/35.73.307/2010, tanggal 19 Juli 2010 dan mendapat sertifikat dengan Nomor Pokok Sekolah Nasional (NPSN): 20570708 pada tanggal 20 September 2010.

Sekolah ini merupakan sekolah yang pertama berbasis IT untuk sekolah tingkat menengah pertama di Kota Malang dan sedang mengembangkan menuju sekolah sehat (green school). Pendirian SMP 
Plus Al-Kautsar Malang seiring dengan tuntutan dan kebutuhan masyarakat Kota Malang dalam menyongsong era Information Technology (IT) dan SMP Plus Al-Kautsar dipersiapkan sebagai model sekolah yang berbasis IT yang terpadu dan menyeluruh dengan fasilitas internet dan intranet dalam pembelajaran dan manajemen administrasi sehingga diharapkan mampu mewujudkan tingkat efisiensi dan efektifitas dalam berbagai aspek kegiatan pendidikan. Hal ini tercermin dari taglinne yang digunakan yaitu "Bernuansa Islami, Berbasis IT, dan Berwawasan Lingkungan".

Visi sekolah SMP Plus Al-Kautsar Malang adalah terwujudnya lulusan sekolah yang beriman ,berilmu, dan beramal shaleh ,unggul dalam prestasi dan memiliki daya saing dalam bidang IPTEK serta berwawasan lingkungan. Sedangkan misi sekolah SMP Plus Al-Kautsar Malang adalah 1) Menumbuh kembangkan sikap, perilaku, dan amaliah keagamaan islam di sekolah; 2) Menumbuhkan semangat belajar ilmu keagamaan islam; 3) Melaksanakan bimbingan dan pembelajaran secara aktif, kreatif dan menyenangkan, sehingga setiap siswa dapat berkembang secara optimal,sesuai potensi yang dimiliki; 4) Menumbuhkan semangat keunggulan secara intensif dan daya saing yang sehat kepada seluruh warga sekolah baik dalam prestasi akademik maupun non akademik; 5) Menciptakan lingkungan sekolah yang sehat, bersih, dan indah; 6) Mendorong, membantu dan memfasilitasi siswa untuk mengembangkan kemampuan, bakat dan minatnya, sehingga dapat dikembangankan secara lebih optimal dan memiliki daya saing yang tinggi; 7) Mengembangakan life skills setiap aktivitas pendidikan; 8) Mengembangkan sikap kepekaan terhadap lingkungan; 9) Menerapkan manajemen partisipatif dengan melibatkan seluruh warga sekolah, komite sekolah dan stakeholders dalam pengambilan keputusan; dan 10) Mewujudkan sekolah sebagai lembaga pendidikan yang mendapat kepercayaan dari masyarakat.

Tujuan sekolah SMP Plus Al-Kautsar Malang adalah mempersiapkan diri sebagai sekolah terpadu, yang menyelaraskan kebutuhan akan kepentingan dunia dan akhirat dan mengembangkan kepekaan emosi dan intelegensia yang baik (EQ dan IQ) dan penguasaan ruhiyah vertical atau Spiritual Quotient (SQ) terhadap peserta didik dalam proses pembelajaran yang berimbang dan 
bermutu, sehingga diharapkan akan mampu menghasilkan ouput yang bermutu secara akademik, karakteristik, spiritualistik dan mampu mengantarkan para alumninya pada kemajuan di masa mendatang yang bertumpu pada 3 (tiga) konsep tersebut. Sehingga dapat menhasilkan lulusan yang tidak hanya dibekali kompetensi duniawi melainkan juga dibarengi kematangan akhlaq.

Sebagai sekolah yang berbasis ICT atau banyak menggunakan perangkat informasi dan teknologi di setiap kegiatan pembelajaran maupun yang lain, SMP Plus Al-Kautsar Malang dilengkapi berbagai sarana dan prasarana yang mendudkungnya. Sarana dan prasarana yang terdapat di SMP Plus Al-Kautsar Malang yang berbasis ICT dalam area akademik maupun administrasi diantaranya: ruang server, server, personal computer (PC) unttuk guru dan karyawan, laptop untuk masing-masing siswa, proyektor LCD di tiap kelas, wifi-reuters, audio, cctv, dan printer. Disamping itu sumber daya manusia yaitu tenaga pendidik dan tenaga kependidikan juga diberikan pembekalan kemampuan untuk dapat memiliki kompetensi penguasaan dasar perangkat ICT.

2. Implementasi Pengintegrasian Imtaq dan Iptek di SMP Plus AlKautsar Malang

Penerapan iptek dalam pembelajaran di SMP Plus Al-Kautsar Malang meliputi bidang kurikulum, strategi pembelajaran, materi pembelajaran, dan penilaian. Penerapan iptek dengan penggunaan perangkat ICT meliputi: pengelolaan dan pengaturan jadwal pembelajaran, materi pembelajaran dan materi ujian yang terintegrasi dengan web sekolah, dan sistem ujiandan penilaian secara online. Sedangkan penerapan iptek dalam administrasi meliputi bidang: tata kelola sekolah, manajemen keuangan, manajemen sarana dan prasarana, data pokok pendidikan, perpustakaan dan keamanan. Penerapan iptek dengan penggunaan perangkat ICT meliputi: pengelolaan data dan informasi di sekolah memanfaatkan teknologi informasi dan komunikasi, pengelolaan berbagai laporan keuangan dengan program komputer khusus, inventarisasi sarana prasarana dengan komputerisasi, pengelolaan data akademik , guru dan siswa yang terintegrasi dalam satu sistem, penggunaan sistem perpustakaan dan keamanan (cctv) yang terkomputerisasi. 
Tidak hanya menerapkan iptek dan berbasis pada penggunaan perangkat komunikasi dan teknologi SMP Plus Al-Kautsar Malang juga berupaya mengintegrasikan imtaq dalam berbagai kegiatan yang ada. Hal ini tercermin dari visi, misi, dan tujuan sekolah SMP Plus AlKautsar Malang yng tidak hanya menekankan penguasaan iptek akan tetapi juga pengintegrasian imtaq dan imtek dalam pembelajarannya. Berikut merupakan beberapa tinjauan pengintegrasian imtaq dan iptek di SMP Plus Al-Kautsar Malang adalah:

a. Menciptakan lingkungan sekolah yang islami

Usaha untuk mengintegrasikan imtaq dan iptek di SMP Plus Al-Kautsar Malang didasarkan pada tagline yang dipergunakan yaitu "Bernuansa Islami, Berbasis IT, dan Berwawasan Lingkungan". Upaya pengintegrasian dilakukan diawali dengan menciptakan lingkungan yang didasarkan pada nilai-nilai keislaman. Beberapa bentuk upaya pengintegrasian imtaq dan iptek adalah: pemisahan antara siswa laki-laki dan perempuan serta penanaman perilaku yang islami pada para siswa baik di dalam dan di luar pembelajaran.

Pemisahan antara siswa laki-laki dan perempuan dalam pembelajaran di kelas masing-masing dimaksudkan untuk meminimalisir pergaulan lawan jenis dan mengantisipasi hal-hal yang tidak diiinginkan. Sebab menurut kepala sekolah hal ini disesuaikan dengan usia remaja yang identik dengan pubertas. Sehingga dibutuhkan pembatasan tertentu. sedangkan penanaman perilaku yang islami sering dilakukan para pendidik dengan cara mengingatkan siswa-siswi ketika bergurau diluar batas antara lawan jenis ketika istirahat ataupun ketika pada saat pembelajaran yang diadakan di luar kelas. Mengingat seringkali pembelajaran dilaksanakan di tempat selain kelas seperti perpustakaan, ruang media, luar kelas atau alam terbuka.

b. Membentuk sumber daya manusia yang islami

Upaya pengintegrasian imtaq dan iptek di SMP Plus Al-Kautsar Malang juga dilakukan dalam tinjauan sumber daya manusianya. Hal ini meliputi pembuat kebijakan (kepala sekolah), tenaga pendidik, dan peserta didik. Kebijakan yang dibuat oleh kepala sekolah dalam hal penerapan iptek seperti kewajiban 
menggunakan laptop pribadi untuk masing-masing siswa dan akses internet dalam setiap pembelajaran sebagai salah satu sumber pembelajaran, tentu membawa dampak tersendiri. Sehingga dibutuhkanlah penerapan imtaq yang diintegrasikan dalam kegiatan para siswa yang bertujuan untuk meminimalisir dampak ditimbulkan dari penerapan iptek. Bentuk pengintegrasian imatq dan iptek diantaranya adalah pembuatan berbagai kebijakan yang mengarah pada pengintegrasian imtaq dan iptek oleh kepala sekolah yang tercermin dalam visi, misi, dn tujuan sekolah. Kemudian diadakannya kegiatan rutin pembacaan al-Qur'an setiap hari nya sebelum pelajaran dimulai, kegiatan rutin mengkaji al-Qur'an (tadabbur), serta fasilitas tahfidz bagi tenaga pendidik dan siswa.

Pengintegrasian imtaq dan iptek oleh kepala sekolah tampak pada kebijakan yang dibuat diantaranya adalah visi sekolah yaitu: terwujudnya lulusan sekolah yang beriman ,berilmu, dan beramal shaleh ,unggul dalam prestasi dan memiliki daya saing dalam bidang IPTEK serta berwawasan lingkungan. Visi sekolah selanjutnya terewajantahkan dalam misi, dan tujuan sekolah yaitu mempersiapkan diri sebagai sekolah terpadu, yang menyelaraskan kebutuhan akan kepentingan dunia dan akhirat dan mengembangkan kepekaan emosi dan intelegensia yang baik (EQ dan IQ) dan penguasaan ruhiyah vertical atau Spiritual Quotient (SQ) terhadap peserta didik dalam proses pembelajaran yang berimbang dan bermutu serta pada berbagai kebijakan-kebijakan sekolah yang dibuat.

Pengintegrasian imtaq dan iptek dalam tinjauan tenaga pendidik adalah dengan mengadakan kajian rutin bagi tenaga pendidik. Hal ini dimaksudkan untuk memperluas khasanah pengetahuan agama bagi para pendidik. Disamping itu disediakan fasilitas tahfidz bagi para pendidik. Hal ini dimaksudkan agar memberikan contoh bagi para anak didik untuk dapat menyeimbangkan antara ilmu pengetahuan dan pengetahuan alQur'an.

Sedangkan pengintegrasian imtaq dan iptek dalam tinjauan perserta didik adalah dilakukannya pembacaan Al-Qur'an setiap 
harinya sebelum pelajaran dimulai. Kegiatan baca al-Qur'an dilaksanakan di jam ke-0 dengan mendatangkan guru khusus dengan metode ummi. Hal ini dimaksudkan agar siswa-siswi juga merasa akrab dengan al-Qur'an dan menumbuhkan kewajiban untuk mempelajarinya disamping ilmu pengetahuan umum. Disamping itu kegiatan mengkaji al-Qur'an (tadabbur) dimaksudkan untuk lebih memberi pemahaman siswa akan hukum-hukum Alloh swt, khususnya membahas perkembangan iptek dalam tinjauan Al-Qur'an. Hal ini dimaksudkan untuk membentengi pada siswa terhadap dampak negatif yang diakibatkan iptek seperti penayalahgunaan internet dan sebagainya. bentuk pengintegrasian imtaq dan iptek yang lain adalah pembacaan doa sebelum dan sesudah diadakannya pembelajaran dan pembinaan ekstrakurikuler yang mendukung seperti kaligrafi dan lainnya.

\section{Kesimpulan}

1. Hubungan antara imtaq dan iptek harusnya tidak dipandang sebagai sesuatu yang dikotomis, justru sebaliknya keduanya saling memberikan manfaat yang sama pentingnya. Pada kenyataannya konsep pendikotomian telah gagal dalam upaya membangun umat. Agama yang terejawantah dalam nilai keimanan dan ketaqwaan dalam diri seseorang akan mengelola bumi dengan bijak. Sedangkan sains akan menuntut manusia untuk meningkatkan kehidupan ke arah yang lebih baik.

2. Pengimplementasian integrasi imtaq dan iptek tidak hanya dilakukan pada saat proses pembelajaran, tetapi harus dilaksanakan dalam seluruh aktivitas kegiatan pendidikan, dan ini membutuhkan komitmen yang kuat dari stakeholder internal sekolah dan juga membutuhkan dukungan dari stakeholder eksternal sekolah.

3. Terdapat empat faktor kunci kesuksesan pengintegrasian Imtaq dan Iptek dalam Pembelajaran, yaitu tenaga pendidik dan kependidikan yang kompeten dalam ikut mendorong kesuksesan integrasi; textbook atau buku yang terpadu dalam mengintegrasikan nilai-nilai keimanan dan ilmu pengetahuan; 
peran penting guru sebagai role model bagi siswa-siswanya; dan adanya ekstrakurikuler yang mendukung.

4. Upaya pengintegrasian imtaq dan iptek di pembelajaran dapat dilakukan dalam dua tinjauan yaitu lingkungan yang islami dan sumber daya yang islami. Lingkungan yang islami dapat terwujud diantaranya dengan cara pemisahan antara siswa laki-laki dan siswa perempuan dalam pembelajaran. Disamping itu monitoring dan pengawasan pergaulan yang sesuai dalam Islam ditanamkan dalam kegiatan-kegiatan pembelajaran. Sedangkan dalam tinjauan sumberdaya islami dapat melalui (i)pembuat kebijakan (kepala sekolah) yang membuat kebijakan-kebijakan yang mengintegrasikan imtaq dan iptek yang tercermin dalam visi, misi dan tujuan sekolah; (ii)tenaga pendidik mengikuti kajian rutin (tadabbur) Al-Qur'an dan penyediaan tahfidz Qur'an bagi para pendidik; serta (iii) bagi anak didik terdapat kegiatan baca AlQur'an setiap pagi sebelum pembelajaran dimulai serta kajian rutin (tadabbur) Al-Qur'an yang membahas perkembangan iptek dalam tinjauan hukum-hukum al-Qur'an, serta melakukan doa di setiap permulaan dan akhir dari pembelajaran. 


\section{DAFTAR PUSTAKA}

Abuddin, Nata dkk. 2002. Integrasi Ilmu Agama dan Ilmu Umum. Jakarta. Raja Grafindo

Ailala,

Yoga.

2014.

http:// www.belajarislam.web.id/ 2014/ 05/ pengertian-imandan-taqwa-dalam-islam.html, diakses tanggal 07 Oktober 2014.

Bagir, Haidar. 1999. Sains Islami: Suatu Alternatif. Jurnal Ulumul Qur 'an.

Bagir, Zainal Abidin dkk. 2005. Integrasi Ilmu dan Agama, Interpretasi dan Aksi. Bandung: Mizan Pustaka Persada

Baharuddin \& Moh. Makin. 2010. Manajemen Pendidikan Islam: Transformasi Menuju Sekolah/Madrasah Unggul, (Malang: UIN-MALIKI Press).

Baiquni, Ahmad. 1997. Al-Qur'an dan Ilmu Pengetahuan Kealaman. Yogyakarta: Dana Bhakti Primayasa.

barbour, Ian G. 2002. Juru Bicara Tuhan: Antara Sains dan Agama, terj. E.R. Muhammad. Bandung: Mizan.

Daryanto. 2007. Kamus Bahasa Indonesia Lengkap. Surabaya: Apollo,.

Dick, Walter, Low Carey dan J.O. Cerey. 2006. The Systematic Design of Instruction. New York: Pearson.

Direktorat Jenderal Manajemen Pendidikan Dasar Dan Menengah Pembinaan Pendidikan Agama Dan Akhlak Mulia, Pemberdayaan Sekolah Berwawasan Imtaq, (jakarta, 2007), hlm. ii

Direktorat Jenderal Pembinaan Kelembagaan Agama Islam Depatemen Agama RI. 1995. Islam untuk Disiplin Ilmu Pengetahuan Alam dan Teknologi . Jakarta: Direktorat Jenderal Pembinaan Kelembagaan Agama Islam.

Elfindri. 2011. Pendidikan Sebagai Barang Ekonomi. Bandung: Lubuk Agung.

Herman, Soewardi. 2001. Mempersipakan Sains Tauhidullah. Bandung: Bakti Mandiri. 
Irsyadunnas. 2003. 'Amar dalam Al-Qur'an (Kajian tentang Ayat-ayat Taqwa), Jurnal Penelitian Agama. Vol. Xii, No. 3, pp: 504-517, hlm. 506.

Kamus Besar Bahasa Indonesia (KBBI). Kamus versi online/daring (dalam jaringan). http:// kbbi.web.id/integrasi , diakses tanggal 07/ 11/2014

Lubis, Maimun Aqsha et al. 2009. Integrated Islamic Education in Brunei Darussalam: Philosophical Issues and Challenges, Journal of Islamic and Arabic Education 1(2), , pp: 51-60

Mulyasa, E. 2010. Implementasi Kurikulum Tingkat Satuan Pendidikan, Kemandirian Guru dan Kepala Sekolah. (Jakarta: PT Bumi Aksara).

Pribadi, A. Benny. 2011. Model Desain Sistem Pembelajaran. Jakarta: Dian Rakyat

Qomar, Mujamil. 2007. Manajemen Pendidikan Islam: Strategi Baru Pengelolaan Lembaga Pendidikan Islam, Penerbit Erlangga.

Sari, Milya. 2002. Pemahaman Ayat-ayat Al Qur'an Melalui Sains dan Teknologi. Jurnal Ilmiah Ta'dib. Vol. 8, No. 8 (Januari-Juni). STAIN Batusangkar.

Sofyan Sauri, Deksripsi Nilai Iman Dan Takwa Dalam Pembelajaran, http:// file.upi.edu/ Direktori/ FPBS/JUR. PEND. BAHASA ARA B/ 195604201983011 -

SOFYAN SAURI/ makalah2/ INTEGRASI IMTAK DAN IMPTEK DALAM PEMBELAJARAN.pdf.

Supriadi, Dedi. 2004. Membangun Bangsa Melalui Pendidikan. Bandung Remaja: Rosda Karya.

UU No 20 tahun 2003 tentang Sistem Pendidikan Nasional

Yamin, Martinis. 2011, Paradigma Baru Pembelajaran.Jakarta: Gaung

Persada.

Yusuf, Ali Anwar. 2000. Islam dan Sains Modern: Sentuhan Islam

Terhadap Berbagai Disiplin Ilmu. Bandung: Pustaka Setia. 
Soelaiman - Integrasi Imtaq dan Iptek dalam Pembelajaran

J-PAI : Jurnal Pendidikan Agama Islam

Vol. 2 No. 2 Januari-Juni 2016 